\title{
Application of Spaceborne Scatterometer for Mapping Freeze-Thaw State in Northern Landscapes as a Measure of Ecological and Hydrological Processes
}

\author{
Kyle MCDONALD ${ }^{(1)}$, John KIMBALL ${ }^{(2)}$, Reiner ZIMMERMANN ${ }^{(3)}$, \\ JoBea WAY ${ }^{(1)}$, Steve FROLKING ${ }^{(4)}$ and Steve RUNNING ${ }^{(2)}$ \\ (1) Jet Propulsion Laboratory, California Institute of Technology \\ Mail Stop 300-233, 4800 Oak Grove Dr., Pasadena, CA 91109 \\ Phone: 818-354-3263 FAX: 818-354-9476; kyle.medonald@jpl.nasa.gov, way @lor.jpl.nasa.gov \\ (2)NTSG School of Forestry, University of Montana, Missoula, MT $\mathbf{5 9 8 0 2}$ \\ Phone: 406-243-6311 FAX: 406-243-4510; johnk@ntsg.umt.edu, swr@ntsg.umt.edu \\ ${ }^{(3)}$ Bayreuth Institute for Terrestrial Ecosystem Research, Department of Plant Ecology \\ University of Bayreuth, D-95440, Bayreuth, GERMANY \\ - \\ Phone: (49)-921-552573 FAX: (49)-921-552564; reiner.zimmermann @ bitoek.uni-bayreuth.de \\ ${ }^{(4)}$ Complex Systems Research Center, Morse Hall \\ University of New Hampshire, Durham, NH 03824 \\ Phone: 603-862-0244, FAX: 603-862-0188; steve.frolking@unh.edu
}

\section{INTRODUCTION}

Landscape freeze/thaw transitions coincide with marked shifts in albedo, surface energy and mass exchange, and associated snow dynamics. Monitoring landscape freeze/thaw dynamics would improve our ability to quantify the interannual variability of boreal hydrology and river runoff/flood dynamics. The annual duration of frost-free period also bounds the period of photosynthetic activity in boreal and arctic regions thus affecting the carbon budget and the interannual variability of regional carbon fluxes.

\section{STUDY DECRIPTION}

We have used the NASA scatterometer (NSCAT), a Ku-band, $25 \mathrm{~km}$ resolution radar flown aboard the ADEOS platform [1], to monitor the temporal change in the radar backscatter signature across Alaska to assess the scatterometer's capability for monitoring freeze/thaw transitions in northern ecotones.

\section{In Situ Measurement Stations}

To support the remote sensing measurements, we established a network of ground stations within selected ecoregions along a north-south transect across Alaska (Table 1 and Fig. 1.) Our Alaska Ecological Transect (ALECTRA) consists of a network of measurement stations, each monitoring vegetation tissue temperature, soil temperature profiles, xylem tissue water flux and micrometeorological parameters in situ. Thermistors are implanted into the hydroconductive tissues of trees' trunks and branches, selected to be representative of the species mix in the ecotone surrounding each ground station. Sampling strategy was designed such that each station's measurement ensemble could be used to provide an estimate of the freeze/thaw transition pattern for large regions surrounding the station. Temperature, xylem flux and meteorological measurements are monitored every 5 minutes, averaged into 2 -hour ensembles, and stored on a 60 channel data logger for subsequent retrieval. Each station is powered by a bank of 12 volt DC deep-cycle lead acid batteries, charged by a set of solar panels.

\section{Scatterometer Data}

NSCAT flew from September 1996 through June 1997, providing approximately 9 months of high-quality data. As the measured backscatter is functionally dependant on incidence angle, the wide-swath measurements were normalized to a reference incidence angle of $40^{\circ}$ so that the temporal sensitivity of backscatter to changing landscape freeze/thaw state could be readily quantified [2]. We then use data from the ground stations to quantify the backscatter sensitivity to landscape freeze/thaw state under a variety of terrain and landcover conditions.

\section{MEASUREMENTS AND RESULTS}

Analysis of NSCAT temporal response over the 1997 spring thaw cycle shows a 3 to $5 \mathrm{~dB}$ change in measured backscatter that is well correlated with the landscape springtime thaw process (Fig. 2). Within the Alaskan Interior, vegetation temperature measurements clearly show a warming trend began on about Day-of-Year (DOY) 92 and lasted about 10 days. A re-freezing trend then began about DOY 102, with 
Table 1: Locations and descriptions of the Alaska Ecological Transect (ALECTRA) ground stations.

\begin{tabular}{|c|c|c|c|}
\hline Region/Climate & In situ Site Locations & Ecotone & Monitored Species \\
\hline \multirow{2}{*}{$\begin{array}{l}\text { Dietrich Valley I } \\
\text { Northern boreal } \\
\text { climate }\end{array}$} & $\begin{array}{l}\text { (a) Northern Dietrich Valley - " } \\
\text { Altigun Pass }\end{array}$ & $\begin{array}{l}\text { Latitudinal tree-line; Closed spruce } \\
\text {-hardwood forest / tundra transition }\end{array}$ & $\begin{array}{l}\text { White spruce, alder, dwarf } \\
\text { arctic birch, willow }\end{array}$ \\
\hline & $\begin{array}{l}\text { (b) Southern Dietrich Valley - } \\
\text { Coldfoot }\end{array}$ & Boggy spruce-hardwood forest & $\begin{array}{l}\text { Black spruce, white spruce, } \\
\text { poplar, birch, willow }\end{array}$ \\
\hline \multirow{2}{*}{$\begin{array}{l}\text { Bonanza Creek } \\
\text { Experimental Forest }{ }^{1} / \\
\text { Boreal continental } \\
\text { climate }\end{array}$} & (a) Floodplain Transect & $\begin{array}{l}\text { Alluvial spruce-hardwood mosaic } \\
\text { forest }\end{array}$ & $\begin{array}{l}\text { White spruce, black } \\
\text { spruce, balsam poplar, } \\
\text { alder }\end{array}$ \\
\hline & (b) Floodplain - Bluff & Alluvial spruce-hardwood forest & $\begin{array}{l}\text { Black spruce, tamarack, } \\
\text { white spruce, aspen }\end{array}$ \\
\hline \multirow{2}{*}{$\begin{array}{l}\text { Denali National Park/ } \\
\text { Southern boreal } \\
\text { climfate }\end{array}$} & (a) Tree Line & $\begin{array}{l}\text { Tree-line at altitude } \\
\text { Open spruce forest }\end{array}$ & $\begin{array}{l}\text { White spruce, willow, } \\
\text { dwarf arctic birch }\end{array}$ \\
\hline & (b) Hillside & Closed spruce-hardwood forest & White spruce, aspen \\
\hline $\begin{array}{l}\text { Kenai Peninsula/ Cool } \\
\text { oceanic climate }\end{array}$ & $\begin{array}{l}\text { (a) Chugach National Forest, } \\
\text { Kenai Fjords National Park }\end{array}$ & Temperate conifer forest & $\begin{array}{l}\text { Sitka spruce, black } \\
\text { cottonwood, sitka alder }\end{array}$ \\
\hline
\end{tabular}

${ }^{1}$ NSF Long-Term Ecological Research (LTER) site

the final spring thaw beginning on about DOY 112, depending on latitude. Examination of NSCAT backscatter shows a clear response to the early thaw conditions, the refreeze, and the onset of the final springtime thaw process. The rise in backscatter during the re-freeze (DOY 102-112) relative to initial frozen conditions is caused by changes in snow properties as the snowpack partially thawed and refroze.

Having verified the instrument's capability to monitor freeze/thaw dynamics, mosaicked data are applied to derive temporal series of freeze/thaw transition maps depicting the spatial and temporal characteristics of springtime thaw processes on a regional scale (Fig. 3.) These maps are derived by comparing multi-temporal backscatter mosaics against a reference mosaic collected during wintertime frozen conditions [3,4] and are compared to maximum air temperature fields, interpolated from measurements acquired from 72 meteorological stations across the region. These maps provide estimates of areal extent of frozen and thawed landscape and demonstrate the utility of spaceborne radar for operational monitoring of seasonal freeze-thaw dynamics and associated biophysical processes for the circumpolar high latitudes [5].

Fig. 4 demonstrates the correlative relationship between radar backscatter and hydrologic processes, contrasting the temporal variation on NSCAT backscatter with steam flow and snow depth during spring thaw. Mean backscatter computed over a $50 \mathrm{~km}$ region surrounding Toolik Lake is compared to stream flow monitored at a gauging station on the nearby Sagavanirktok River. These results demonstrate the potential of the scatterometer for measuring the timing of surface freeze-thaw transitions and associated shifts in hydrologic activity.

\section{ACKNOWLEDGMENTS}

This work was performed at the Jet Propulsion Laboratory, California Institute of Technology, under contract to the National Aeronautics and Space Administration.

\section{REFERENCES}

[1] Naderi, F. M., M. H Freilich, and D. G. Long, "Spaceborne Radar Measurement of Wind Velocity Over the Ocean -- An Overview of the NSCAT Scatterometer System," Proc. IEEE, vol. 79, no. 6, June 1991.

[2] Kennett, R.G., and F. Li, "Seasat over-land scatterometer data, Part I: Global overview of the Ku-band backscatter coefficients," IEEE Transactions on Geoscience and Remote Sensing, 25, pp. 592- $=605,1989$.

[3] Frolking, S., K. McDonald, J. Kimball, J. B. Way, R. Zimmermann, and S. W. Running, "Using Space-borne NASA Scatterometer (NSCAT) to Determine the Frozen and Thawed Seasons of a Boreal Landscape," Journal of Geophysical Research - Atmospheres, in press.

[4] Rignot, E., and J.B. Way, "Monitoring freeze-thaw cycles along north-south Alaskan transects using ERS-1 SAR," Remote Sensing of Environment, 49, pp. 131-137, 1994.

[5] Running, S. W., J. B. Way, K. McDonald, J. Kimball, S. Frolking, "Recent Advances in the use of Satellite Radar Data to Monitor Freeze/Thaw Transitions in Boreal Regions," AGU EOS Newsletter, in press. 


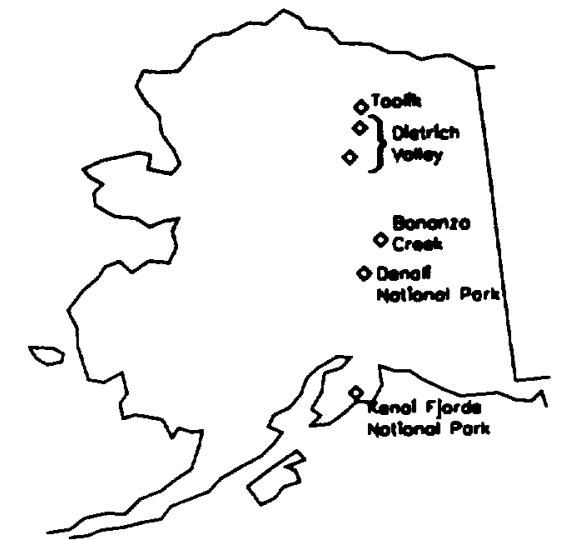

Fig.1: Locations of the ALECTRA ground stations used to quantify the backscatter sensitivity to landscape freeze/thaw state. The Long-Term Ecological Research (LTER) station at Toolik Lake is used to examine snowcovered tundra.
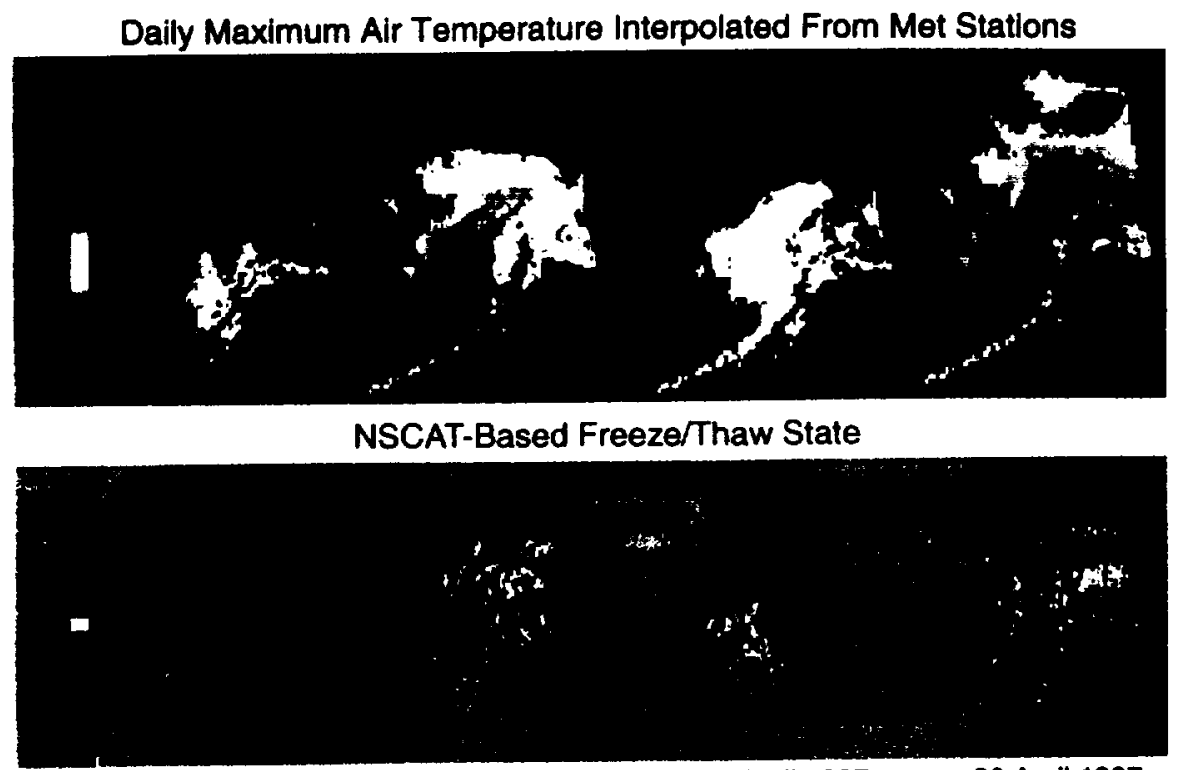

31 March 1997

12 Aoril 1997

20 Aoril 1997

26 Aoril 1997

Fig. 3: Comparison of interpolated maximum air temperature fields with freeze/thaw state maps derived from NSCAT 2-day composite mosaics.

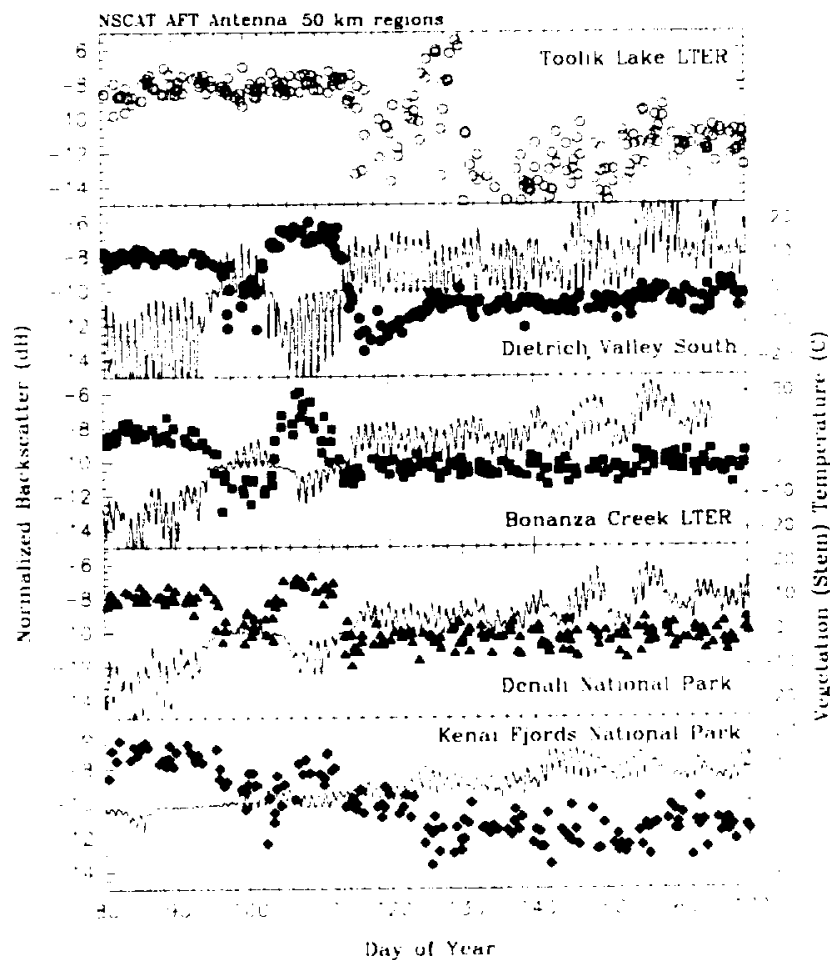

Fig.2: Comparison of temporal series of normalized NSCAT backscatter for 5 regions. Backscatter is compared to temperature measured in the trunk of a single individual of the dominant species at the in situ stations. Each NSCAT data point represents mean backscatter computed over a $50 \mathrm{~km}$ region centered at the respective ground station location.

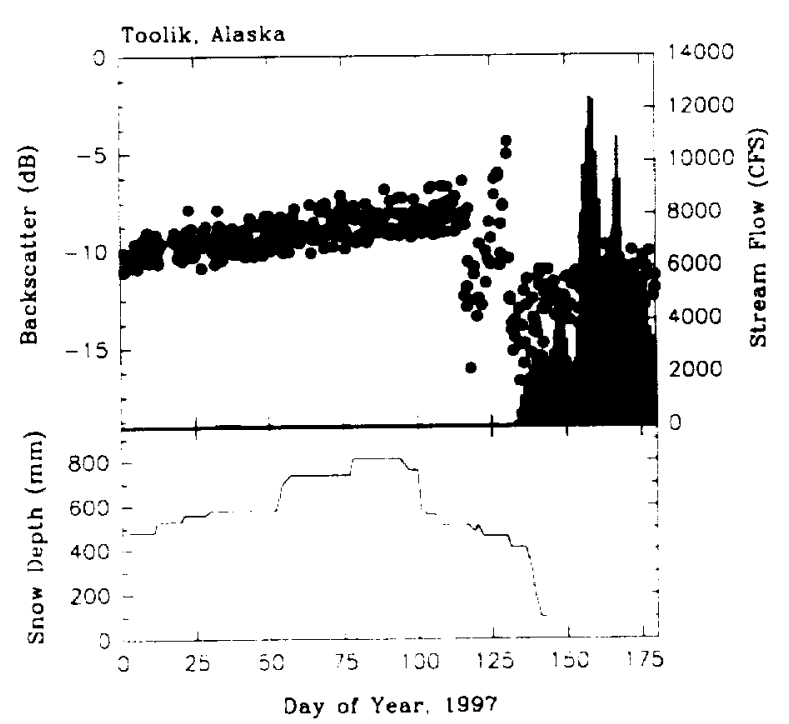

Fig. 4: Comparison of NSCAT backscatter to (top) stream flow in cubic feet per second (CFS) and (bottom) snow depth $(\mathrm{mm})$ for the region near Toolik Lake, Alaska on the north slope of the Brooks Range. Stream flow was monitored at a USGS station on the Sagavanirktok River. 